\title{
O DEBATE PARADIGMÁTICO E O MODELO HEGEMÔNICO DE DESENVOLVIMENTO: do agrário para o rural $^{1}$
}

\author{
EL DEBATE PARADIGMÁTICO Y EL MODELO HEGEMÓNICO \\ DE DESARROLLO: del agrario al rural
}

\author{
Maria Messias F. Lima \\ Doutoranda do Programa de Pós-Graduação em Geografia da UFPB \\ Mestre em Economia Rural pela UFC \\ Professora do Departamento de Economia da URCA \\ limammferreira@gmail.com
}

\begin{abstract}
Resumo
O texto apresenta uma narrativa que se contrapõe ao pensamento dominante sobre a mudança paradigmática do desenvolvimento, que adota o rural em substituição ao agrário como parte da solução para os problemas relacionados ao campo brasileiro. O objetivo principal é provocar uma discussão sobre a essência desse modelo de desenvolvimento institucionalizado na década de 2000, considerando-o como parte de um processo maior que institucionaliza um reordenamento no uso e ocupação do espaço rural pelo capital mundializado, iniciando um novo ciclo de acumulação imprescindível para o desenvolvimento das forças produtivas atuais. O texto foi construído a partir das discussões teóricas que permearam a literatura sobre o futuro do espaço agrário, centrando-se em compreender a mudança de paradigma que desloca a questão agrária para o desenvolvimento rural. A narrativa apresenta os aspectos que foram delineados nos governos FHC e Lula, que teoricamente apresentaram diferenças, mas que em essência representou uma continuidade do modelo neoliberal e o fortalecimento das forças conservadoras que impedem qualquer mudança na estrutura agrária e, portanto, impedindo uma real mudança social no campo brasileiro, limitando-se apenas em atender demandas de segmentos específicos e de curto prazo, impossibilitando, de fato, o desenvolvimento rural sustentável no espaço agrário brasileiro.
\end{abstract}

Palavras-chaves: Expansão capitalista. Questão agrária. Desenvolvimento rural.

\section{Resumen}

El texto presenta una narrativa que se contrapone al pensamiento dominante sobre el cambio paradigmático del desarrollo, que adopta el rural en sustitución al agrario como parte de la solución a los problemas relacionados al campo brasileño. El objetivo principal es provocar una discusión sobre la esencia de ese modelo de desarrollo institucionalizado en la década de 2000, considerándolo como parte de un proceso mayor que institucionaliza un reordenamiento en el uso y ocupación del espacio rural por el capital mundializado, iniciando un nuevo ciclo de acumulación imprescindible para el desarrollo de las fuerzas productivas actuales. El texto fue construido a partir de las discusiones teóricas que permearon la literatura sobre el futuro del espacio agrario, centrándose en comprender el cambio de paradigma que desplaza la cuestión agraria hacia el desarrollo 
rural. La narrativa presenta los aspectos que fueron delineados en los gobiernos FHC y Lula, que teóricamente presenta diferencias, pero que en esencia representó una continuidad del modelo neoliberal y el fortalecimiento de las fuerzas conservadoras que impiden cualquier cambio en la estructura agraria y, por lo tanto, impidiendo un real cambio social en el campo brasileño, limitándose apenas en atender demandas de segmentos específicos y de corto plazo, imposibilitando, de hecho, el desarrollo rural sostenible en el espacio agrario brasileño.

Palabras clave: Expansión capitalista. Cuestión agraria. Desarrollo rural.

\section{Introdução}

Após a superação da década perdida (1980), o controle da inflação na década de 1990 e a adequação do Estado às exigências do modelo neoliberal, o Brasil inicia uma fase de equilíbrio do ponto de vista econômico, que segue até o final dos anos 2000. Contudo, as desigualdades sociais e os conflitos no campo evidenciam que muito do discurso positivista não alcançou a essência dos reais problemas estruturais causadores da crescente desigualdade que se materializa na posse e o uso do espaço agrário brasileiro. A homogeneização e padronização de processos produtivos tornou-se obrigatória provocando uma fissura na divisão internacional do trabalho e um reordenamento na organização do espaço possibilitando uma maior exploração da classe trabalhadora e a espoliação escalar das riquezas naturais, garantindo uma valorização do capital de forma mais ofensiva e rápida.

Em meio a esse cenário, o governo do presidente Fernando Henrique Cardoso (FHC) é pressionado, por um lado, para cumprir a agenda neoliberal e, por outro, os movimentos sociais exigem políticas para o campo, e têm como principal ponto de reinvindicação a reforma agrária. Inicia-se, portanto, um novo padrão de políticas públicas que deveriam cumprir prioritariamente com duas demandas do cenário mundial: garantir a expansão e valoração do capital no espaço agrário, e restringir os conflitos sociais.

A busca pela acumulação e espoliação dos espaços é comandada pelo capital globalizado que, sem pátria busca se expandir indefinidamente. Esse processo exige o uso do espaço agrário pelas grandes corporações ao mesmo tempo que esse espaço é negado para os trabalhadores que vivem e trabalham no campo. $\mathrm{O}$ espaço agrário precisa ser cooptado pelo capital, exigindo o seu uso também para o desenvolvimento de atividades não-agrícolas aptas para a exploração capitalista dos seus recursos materiais e imateriais. 
Novamente, em meio ao projeto neoliberal, o desejo utópico de alcançar o desenvolvimento assume os contornos das políticas públicas e dos debates acadêmicos, construindo os fundamentos, regulamentações e justificativas para as ações planejadas de mais um modelo de desenvolvimento, que encena surpresa pela realidade da pobreza e exclusão no campo e na cidade, encena também compromisso em superar as mazelas que se perpetuam de forma intrageracional.

Se por um lado ocorre o avanço do capital, por outro, a luta pela reforma agrária e dignidade dos trabalhadores no campo ganha força com a redemocratização do Estado abrindo espaço para a organização e consolidação dos movimentos sociais. Entretanto, o enfrentamento a esse problema exige o reconhecimento de que o modelo de produção socioespacial estabelecido é a causa primeira das desigualdades sociais existentes, necessitando de ações que promovam um reordenamento estrutural no país, desconcentrando a propriedade da terra e a forma de produção e apropriação da riqueza social.

As políticas para o campo, historicamente estiveram atreladas aos modelos de desenvolvimento agrícola, caracterizados pela mecanização da agricultura patronal produtora de produtos agrícolas para exportação, atualmente transformados em commodities. Responsável pelo crescimento econômico em décadas anteriores, a modernização agrícola foi utilizada como padrão de desenvolvimento para a expansão do capitalismo no campo de forma desigual e conservadora.

A partir da década de 1990 foram gestadas novas estratégias para o setor, incorporando também os pequenos agricultores que tivessem possibilidades de integração ao capital. Essas estratégias seguiram articuladas com o novo padrão de acumulação, centradas na globalização, nos fundamentos do neoliberalismo e na financeirização da economia, que a partir das recomendações e orientações dos organismos internacionais ocorresse um alinhamento com os interesses do capital que se acumula na esfera mundial, exigindo dos países em desenvolvimento uma reorientação dos gastos públicos e do papel do Estado frente a dinâmica do capital na esfera global que comanda o desenvolvimento de novas forças produtivas. Contudo, o plano apresentado e pactuado com a elite do atraso, diverge das demandas presentes na luta pela reforma agrária.

O cenário de pobreza, exclusão social e conflitos no campo começou a gerar impactos negativos que dificultariam a expansão capitalista, necessitando de uma agenda 
de ações coordenadas e orientadas pelos organismos internacionais, principalmente o Banco Mundial e o Fundo Monetário Internacional (FMI). Após estudos sobre os problemas econômicos e sociais do país, diagnosticaram que a solução passava, primeiramente pela vertente teórica neoliberal e, posteriormente, pela adoção de uma estratégia de desenvolvimento para o campo em que se exige a superação da concepção setorial do espaço agrário para um patamar mais amplo, o rural, determinando assim um reordenamento econômico e social das suas funções, promovendo uma mudança paradigmática do agrário para o rural.

Para desenvolver esse raciocínio sobre a mudança paradigmática do agrário para o rural, iniciado com o governo FHC e tendo continuidade no governo de Luís Inácio Lula da Silva, o texto foi estruturado em duas partes, além dessa introdução e considerações finais. A primeira parte aborda a mudança paradigmática do agrário para o rural, em que mostra o início desse processo ainda na década de 1990 com a agenda neoliberal colocada em prática pelo governo FHC. A segunda apresenta o desenvolvimento rural, institucionalizado pelo governo Lula como hegemônico e que se estrutura nas demandas do grande capital mundializado, caracterizando-se como política de subordinação para o espaço agrário brasileiro. Dessa forma, tem-se uma continuidade da agenda neoliberal, que age de forma escalar e padronizada para favorecer o desenvolvimento de um novo ciclo de acumulação e fortalecer as estruturas de poder vigentes.

\section{A mudança paradigmática: do agrário para o rural}

A partir da década de 1990 foram gestadas novas estratégias para o campo, articuladas com o novo padrão de acumulação capitalista, centradas na globalização, nos fundamentos do neoliberalismo e na financeirização da economia. Esse modelo seguiu as recomendações e orientações dos organismos internacionais para que, na prática ocorra um alinhamento com os interesses do capital mundializado, exigindo dos países subdesenvolvidos uma reorientação dos gastos públicos e do papel do Estado frente a dinâmica do capital na esfera global que comanda o desenvolvimento de novas forças produtivas. 
O modelo de desenvolvimento implementado na segunda metade do século XX, considerada como a modernização do atraso, conseguiu o crescimento e fortalecimento da agricultura patronal produtora de commodities, apesar do Brasil ser detentor de uma extensa fronteira agrícola, condições favoráveis em termos de terra e mão-de-obra, o Estado optou por expulsar os pobres do campo e garantir a concentração fundiária como reserva para o capital. Dessa forma a elite agrária/política, conseguiu paralisar o processo natural de desenvolvimento. Esse padrão, de acordo com Sachs (2001, p. 76) permitiu:

[...] promover uma agricultura moderna de grãos nas frentes pioneiras do Oeste, que prescinde quase inteiramente de mão-de-obra; realizar uma colonização socialmente capenga e ambientalmente predatória na Amazônia; jogar milhões de refugiados do campo nas favelas, engrossando o exército de bóias-frias e deixando centenas de milhares sem terra e sem perspectiva de urbanização efetiva [...].

No final do século XX, o empoderamento dos movimentos socioterritoriais ${ }^{2} \mathrm{e}$ em especial o movimento dos trabalhadores sem-terra (MST), colocou novamente em pauta a necessidade da reforma agrária e acesso às políticas de crédito para o segmento da população rural que vivia às margens das políticas públicas.

No processo de redemocratização do país, no início dos anos 1980, era forte a pressão tanto por parte do sindicalismo rural, quanto do emergente Movimento dos Trabalhadores Sem Terra (MST), para que o tema da reforma agrária compusesse o conjunto de bandeiras da Aliança Democrática. No entanto, estava em debate a possibilidade de o Estatuto da Terra, instrumento legal produzido no regime militar, poder ser a base para a democratização da posse da terra. Em um novo contexto político, tanto as oposições sindicais como o MST defendiam que era necessária uma nova lei, capaz de dar suporte a uma ampla distribuição fundiária, uma vez que, na sua compreensão, o Estatuto acabara se tornando um impulsionador da modernização e da expropriação (MEDEIROS, 2015, p. 346).

Contudo, o plano apresentado e pactuado com a elite do atraso e com os organismos internacionais diverge das demandas presentes na luta pela reforma agrária. O cenário de pobreza, exclusão social e conflitos no campo começou a gerar impactos negativos que dificultariam a expansão capitalista, necessitando, portanto, de uma agenda de ações financiadas, coordenadas e orientadas pelos organismos e órgãos de intervenções internacionais, principalmente o Banco Mundial e o Fundo Monetário Internacional FMI). Com o desenvolvimento de novas concepções sobre as funções do campo no processo de acumulação, a dicotomia campo cidade desaparece, emergindo um espaço multifacetado, ajustável aos novos padrões hegemônicos de produção, o espaço rural. 
Como uma categoria sociológica, o espaço rural foi considerado pelo meio acadêmico-científico como o contrário de espaço urbano, sendo essa perspectiva superada com a urbanização e modernização do campo, eliminando essa distância entre os espaços urbanos e rurais, sendo este último ofertante de uma multiplicidade de usos para o capital.

O desenvolvimento rural consolida a ampliação da escala de produção no campo, perpassa a dimensão agrícola ascendendo para a dimensão rural. Nessa transmutação de um para outro a questão agrária torna-se secundária. Esse paradigma, do desenvolvimento rural, teve sua gênese nas discussões teóricas que fundamentaram o planejamento das políticas públicas para o campo na década de 1990, que se estruturaram no paradigma do capitalismo agrário, em que o espaço rural deve ser reestruturado considerando às exigências advindas da ampliação do comercio internacional e das novas demandas do mercado globalizado exigindo-se uma reestruturação do espaço para a exploração capitalista, envolvendo tanto os recursos naturais quanto os recursos humanos.

Dessa forma, as estratégias de desenvolvimento para o campo provocaram uma ruptura teórica e conceitual que sustentava o paradigma da questão agrária, consolidando o desenvolvimento rural como estratégia hegemônica de desenvolvimento, tendo como principal característica a produção de valores de troca.

Portanto as narrativas de inspiração neoliberal reacenderam o desejo utópico de alcançar o desenvolvimento e o Estado assume a modelagem das políticas públicas e dos debates acadêmicos, construindo os fundamentos, regulamentações e justificativas para as ações planejadas de desenvolvimento, que promove a metamorfose do agrário para o rural. Essa transformação conceitual afasta da agenda governamental a necessidade da reforma agrária como ação prioritária para o desenvolvimento sustentável, contudo, enquanto a questão agrária perde espaço na agenda governamental, ganha impulso nos movimentos sociais, que tentam retardar o avanço da exploração capitalistas dos recursos humano e materiais do campo.

O planejamento desse novo modelo vinculou-se ao fortalecimento tanto da agricultura patronal quanto da agricultura familiar capaz de absorver processos tecnológicos, integrando-se ao circuito mercadológico da reprodução ampliada de capital. Nesse contexto, dois campos de ideias se formaram, os defensores do capitalismo agrário, e os defensores da questão agrária. De acordo com Fernandes (2015) esse modelo é caracterizado pelo conflito que ocorre entre as políticas públicas emancipatórias e as 
políticas de subordinação que se estruturam ideologicamente no conflito teórico entre o paradigma da questão agrária e do capitalismo agrário, tornando-se concretas na ação do Estado. Do ponto de vista da mudança paradigmática ela ocorre como prioritariamente pela expansão capitalista que necessita ampliar sua escala de valoração, colocando no circuito da acumulação de capital novos espaços para exploração, sendo portanto o desenvolvimento rural uma fase de amadurecimento da expansão do capital globalizado que se apropria do espaço rural, essa apropriação iniciou-se através das políticas públicas de promoção do desenvolvimento do capitalismo agrário.

Nesse sentido, existem duas vias para a atuação do Estado no planejamento e execução das políticas públicas para o campo, uma delas leva ao desenvolvimento agrário, que passaria pela realização da reforma agrária e a afirmação do camponês como classe social que se opõe ao agronegócio e mantém de forma permanente a disputa com o capital pelo território. A outra via, passa pela expansão das relações capitalistas no campo, transformando o camponês em agricultor familiar, integrando-o ao mercado, às cadeias produtivas do agronegócio e do capital financeiro. Portanto, a opção de seguir a via do capitalismo agrário ao invés do desenvolvimento agrário, garantiu o alinhamento com o grande capital e as possibilidades para sua expansão, através do desenvolvimento territorial rural. Dessa forma, a compreensão dessa mudança de paradigma converge para a narrativa desenvolvida por Fernandes (2015, p. 390).

O paradigma da questão agrária está disposto em duas tendências: a proletarista, que tem como ênfase as relações capital trabalho, entende o fim do campesinato como resultado da territorialização do capital no campo; a campesina que tem como ênfase as relações sociais camponesas e seu enfrentamento com o capital. Para o paradigma do capitalismo agrário, as desigualdades geradas pelas relações capitalistas são um problema conjuntural e pode ser superado por meio de políticas que possibilitem a 'integração' do campesinato ou 'agricultor de base familiar'. [...] Em síntese, para o paradigma da questão agrária, o problema está no capitalismo e para o paradigma do capitalismo agrário, o problema está no campesinato.

Esse direcionamento de política pública exigiu a superação setorial da agricultura para um patamar mais amplo, o rural, determinando assim um reordenamento econômico das suas funções. As principais referências para a elaboração desse modelo partiram dos resultados do projeto rurbano ${ }^{3}$, constatando que estava em curso o desenvolvimento de um "novo" rural, requalificando os pressupostos que serviram de base para elaboração de políticas públicas para o campo em décadas anteriores, sendo 
estes fundamentais para a compreensão das novas estratégias delineadas pelo movimento feito pelo capital para se expandir globalmente.

De acordo com os autores, Graziano da Silva; Grossi e Campanhola (2002) os resultados mostraram que a narrativa construída, de que o campo representa o atraso; que se limita à produção agrícola e que o êxodo rural é inevitável, precisa ser realinhada com as novas funcionalidades do espaço agrário brasileiro e, nesse contexto uma nova narrativa se apresenta, tornando-se dominante. Os principais pontos dessa narrativa são: expansão do agronegócio, ênfase nas atividades rurais não-agrícolas, e a inviabilidade da reforma agrária como instrumento para o desenvolvimento rural. Em linhas gerais os pressupostos que sustentam o novo rural se estruturam da seguinte forma:

Uma agropecuária moderna, baseada em commodities e intimamente ligada às agroindústrias; Um conjunto de atividades não-agrícolas, ligadas à moradia, ao lazer e a várias atividades industriais e de prestação de serviços; Um conjunto de novas atividades agropecuárias, impulsionadas por nichos especiais de mercados (GRAZIANO DA SILVA; GROSSI; CAMPANHOLA, 2002, p. 39).

Dessa forma, as estratégias para o desenvolvimento do campo brasileiro são reorientadas para que novos espaços sejam incluídos no circuito mercantil D - M - D' em que as atividades rurais não agrícolas se tornam peças fundamentais para a integração entre capitais agrários, industriais, comerciais e financeiros. Segundo Graziano da Silva, Grossi e Campanhola (2002, p. 42)

\begin{abstract}
A grande diferença em relação ao tradicional processo de agregar valor por meio da industrialização reside no fato de que as novas atividades geradas nos anos 90 não decorrem somente de demandas intermediárias no interior das cadeias produtivas. [...] Agora, as novas atividades ganham impulso a partir de uma dinâmica que tem a ver mais com as demandas específicas de grupos de consumidores de média e alta renda dos grandes centros urbanos do País.
\end{abstract}

Contudo, na segunda metade da década de 1990 o governo Federal teve que lidar com a pressão dos sindicatos e movimentos sociais diante de uma realidade incontest, pobreza, exclusão social e conflitos agrários, que se mostraram crescentes no primeiro mandato do presidente FHC (1995 - 1998). Entre 1993 e 1998 os conflitos no campo aumentaram significativamente, tendo como o principal articulador da luta pela terra o MST, tornando-se um dos maiores e mais fortes movimentos em defesa da reforma agrária e da dignidade do trabalhador rural. 
O Gráfico 01 mostra a evolução dos conflitos, ocupações e assentamentos criados, com ênfase nos dois mandatos do presidente FHC e no primeiro ano do primeiro mandato do presidente Lula. As informações sobre conflitos e ocupações no campo nesse período são fundamentais para o debate e reflexão sobre as ações e intenções dos governos, sejam eles, liberais ou populistas, para o planejamento do modelo hegemônico de desenvolvimento rural. Observa-se que entre 1993 e 1998 existe uma explosão dos conflitos no campo contabilizados para o último ano, um total de 1.100, sendo o Massacre de Eldorado dos Carajás em 1996 o mais violento, deixando 19 trabalhadores mortos e mais de 70 em estado grave. Entre 1996 e 1999 houve também o maior número de ocupações, contribuindo com um avanço em relação ao número de assentamentos criados.

Gráfico 01 - Brasil - Número de conflitos*, ocupações no campo* e assentamentos

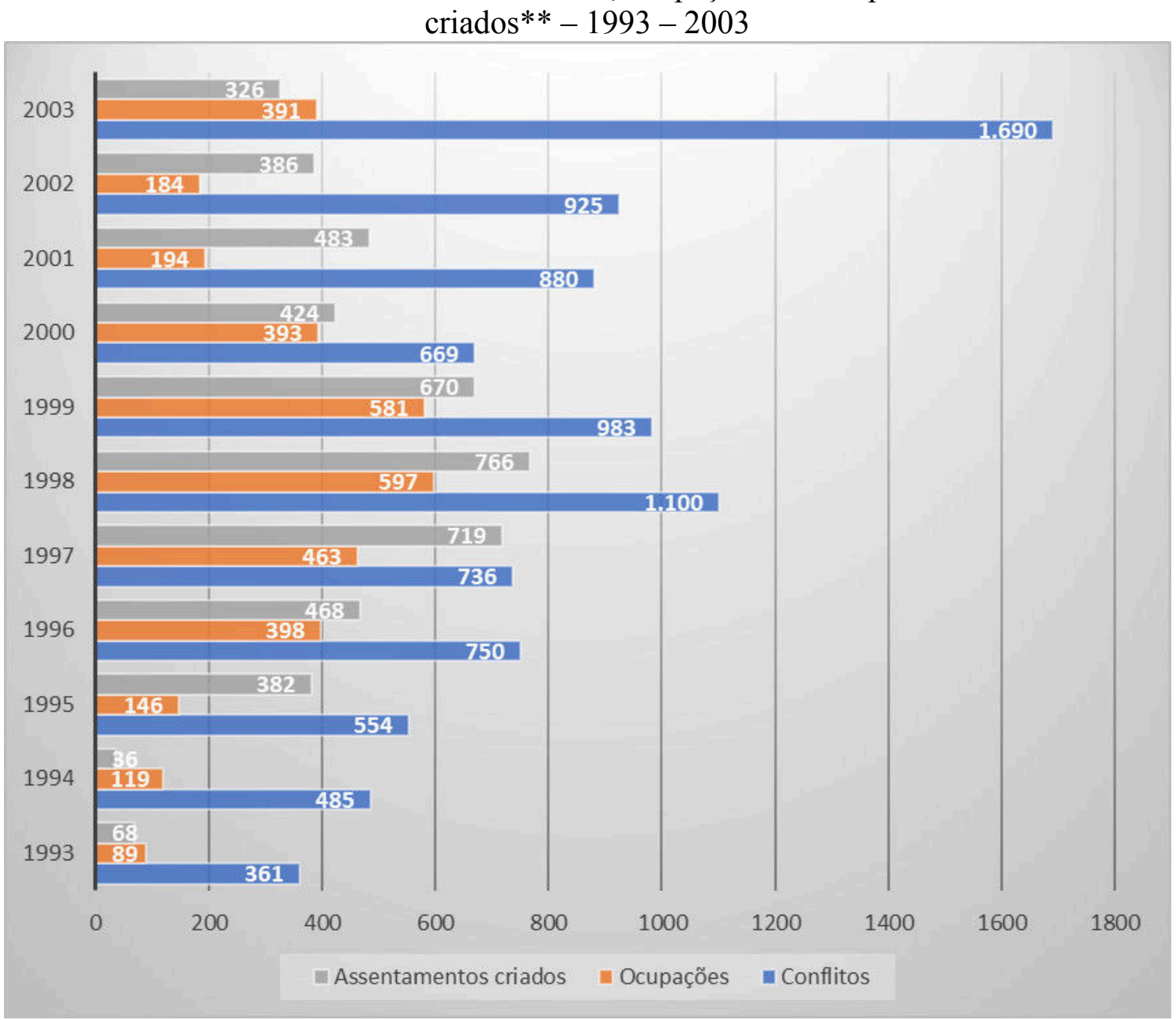

Fonte: Adaptado da CPT Nacional, 2004 e 2005. NERA/DATALUTA, 2014.

* Dados adaptados da CPT Nacional - Conflitos no Campo, 2004 e 2005

**Dados adaptados do Banco de dados do DATALUTA, Relatório Brasil, 2014. 
Nesse contexto, como forma de conter a pressão que os trabalhadores sem-terra organizados exerciam sobre o Estado o presidente FHC editou uma Medida Provisória (MP) no ano 2000 e outra em 2001 penalizando e reprimindo o Movimento em dois pontos: as áreas ocupadas não seriam desapropriadas e, os trabalhadores que participassem de ocupações não seriam beneficiários dos projetos de reforma agrária. Soma-se a isso a violência que vitimou vários líderes de movimentos e sindicalistas que resistiam à repressão autorizada e a não autorizada pelo Estado, aumentado a violência no campo como resposta às demandas pela democratização da posse e uso do espaço agrário. Evidencia-se, portanto, que no segundo mandato do presidente FHC (1999 e 2002) houve uma maior repressão e criminalização contra a luta pela terra, acarretando em uma redução tanto nos conflitos e ocupações quanto na criação ${ }^{4}$ de novos assentamentos.

Portanto o cenário posto a partir da década de 1990 em torno da questão agrária e as estratégias traçadas para eliminar a pressão sobre o Estado para a realização de uma reforma agrária orgânica foi desvirtuada pelas forças conservadoras que se concretizam inicialmente na repressão aos movimentos e, posteriormente por um modelo que reforça as estruturas de poder, impedindo um efetivo desenvolvimento para o campo, incluindo os trabalhadores, povos tradicionais, soberania alimentar e preservação ambiental.

\begin{abstract}
No governo $\mathrm{FHC}$ os principais programas ligados à questão fundiária foram: O Cédula da Terra, o Banco da Terra e o Crédito Fundiário. Na mesma linha de atuação em 1997 foi promovido o Programa de Consolidação da Agricultura Familiar (PAC) que tinha como propósito promover a consolidação e emancipação de assentamentos rurais com a viabilidade de determinado aporte de recursos financeiros e a oferta de infraestrutura básica, como estradas, energia elétrica e acesso à água. Na prática, esperava-se que uma vez concretizado essas ações, [...] as condições básicas estariam garantidas para que os assentados recebam seu título definitivo, se constituindo em agricultores familiares, integrados ao agronegócio. (REZENDE \& MENDONÇA, 2004, p. $18)$.
\end{abstract}

A eleição de 2002 que levou Luís Inácio Lula da Silva à presidência, promoveu uma forte expectativa para os movimentos sociais em relação ao atendimento das suas demandas e reinvindicações. Surgia, portanto a possibilidade real de colocar em prática um projeto de desenvolvimento com menos desigualdade e maior inclusão social. Esse projeto exigia e ainda exige o enfrentamento aos interesses das velhas oligarquias agrárias, fortemente ligadas ao grande capital financeiro mundializado. Contudo, no primeiro ano do seu governo foi registrado o maior número de conflitos no campo, 1.690. 
Segundo Silva \& Fernandes (2005) no mesmo ano foram assentadas 35.623 famílias, destas $24 \%$ em terras desapropriadas ou compradas e $76 \%$ em assentamentos já criados.

Os gráficos 02 e 03 mostram, de forma sucinta, o direcionamento que o presidente Lula deu para os conflitos que emergiram a partir de meados dos anos de 1990 e seguiram nos anos 2000 decorrentes da luta pela terra, água e trabalho. Um comparativo entre o $2^{\circ}$ mandato de FHC e o $1^{\circ}$ mandato de Lula mostra claramente que, embora de forma tímida e sob muita pressão dos movimentos sociais, o governo $\mathrm{FHC}$ foi quem mais desapropriou terras para a reforma agrária, representando $98,6 \%$ dos assentamentos criados no período de 1999 a 2002.

Gráfico 02 - Percentual de assentamentos criados, famílias assentadas e área destinada para reforma agrária no $2^{\circ}$ Mandato de $\mathrm{FHC}$

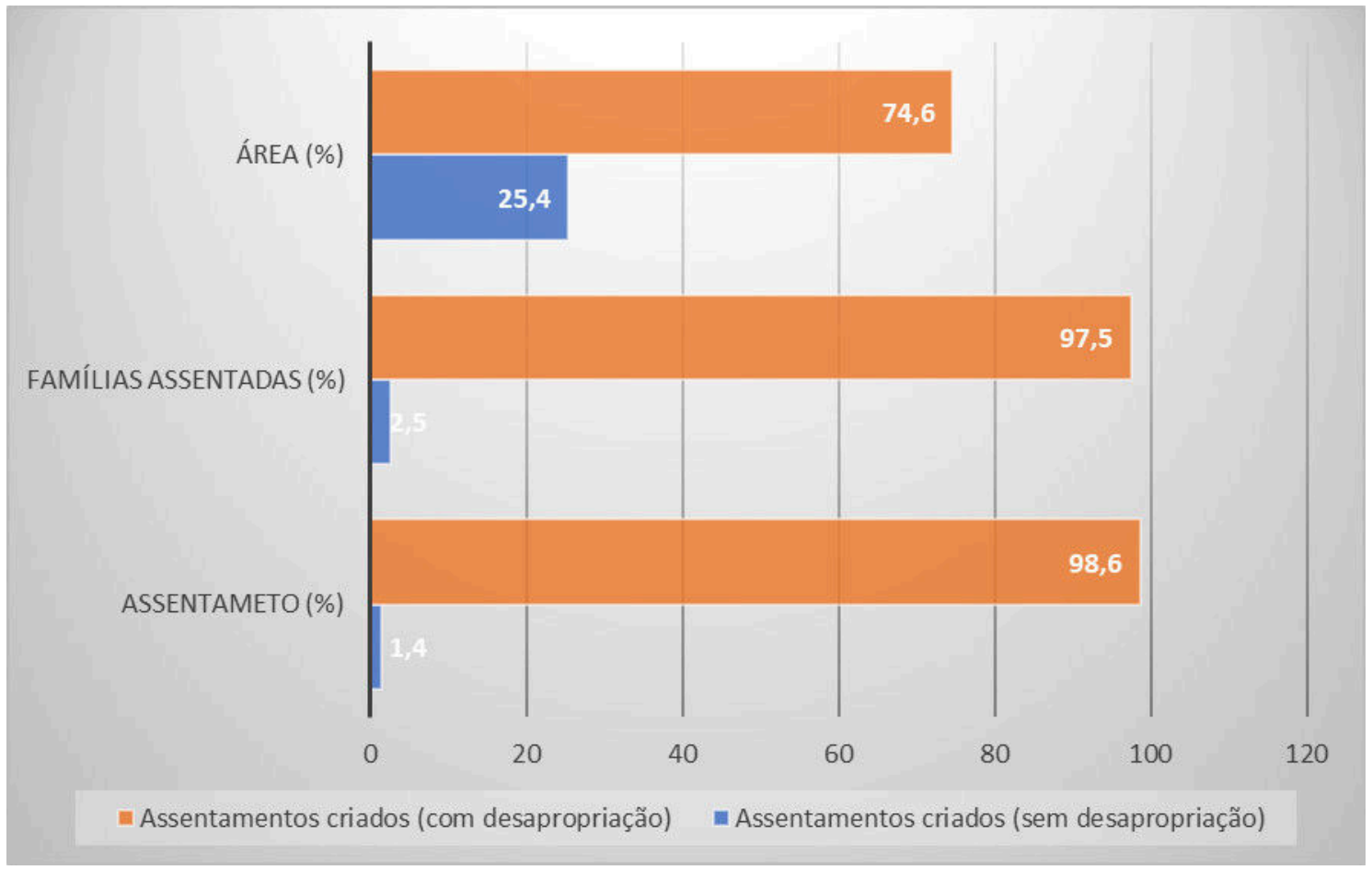

Fonte: Adaptado de Girardi, 2017.

Contudo, a análise não deve se limitar apenas à leitura quantitativa dos dados, mas penetrar na realidade não quantificada, porém concreta e permeada pelas contradições presentes nas urdiduras do próprio sistema. Nesse sentido, Fernandes (2003) faz uma análise crítica essencial para a compreensão das políticas públicas para o campo que seguiram nos anos 2000. 
Embora FHC tenha propagandeado que realizou a maior reforma agrária da história do Brasil, essa realidade produziu dois resultados lamentáveis: o represamento com o crescimento do número de famílias acampadas, [...] e a precarização dos assentamentos implantados, que foram implantados como projetos incompletos, que além de não terem infra-estrutura básica, a maior parte também não recebeu crédito agrícola e de investimento. Na verdade, o governo FHC nunca possuiu um projeto de reforma agrária. Durante os mandatos de seu governo, $90 \%$ dos assentamentos implantados foram resultados de ocupações de terra (p. 03).

Esse processo de criação de assentamentos resultou em outros problemas para os trabalhadores assentados, pois não receberam as condições mínimas para o trabalho e vida nos assentamentos, gerando muitas dificuldades que em muitos casos eram obrigados a deixar suas parcelas para tentar a sobrevivência nas periferias das grandes cidades. A narrativa dada para esse cenário corroía a defesa para a viabilidade de uma reforma agrária efetiva. Para corroborar com esse discurso o Banco Mundial passa a comandar um projeto de reforma agrária que, em tese, seria mais eficiente, mais barato e menos burocrático.

O modelo de reforma agrária definido pelo Banco Mundial como mais viável atendia a lógica do projeto neoliberal, marca do governo FHC. Contudo, o velho se reveste de novo e as velhas estruturas de poder coordenam um projeto de reforma agrária que mantém intacta a concentração de riqueza, terra e poder. Ou seja, o modelo adotado, não atendeu as principais demandas dos movimentos sociais que somente seriam atendidos com a implantação de uma reforma agrária capaz de romper com a concentração fundiária e a pobreza no campo, principais pontos da questão agrária brasileira.

De acordo com Oliveira (2008) as estatísticas divulgadas pelo INCRA como sendo ações efetivas de reforma agrária, podem ser classificada em quatro categorias: reordenação fundiária, regularização fundiária, reassentamento fundiários de famílias atingidas por barragens e reforma agrária, sendo que apenas essa última se configura de fato em ações concretas de desconcentração fundiária. No entanto, foi promovido um novo modelo de reforma agrária que ficou conhecido como reforma agrária de mercado. O principal programa desse modelo foi o Cédula da Terra. De acordo com Pereira (2013) esse modelo não apresentava nenhuma intenção de modificar a estrutura agrária vigente, sendo rejeitado, tanto pelo MST como pela Confederação Nacional dos Trabalhadores na Agricultura (CONTAG). 
Nesse sentido, a vitória nas urnas obtida pelo presidente Lula, criou possibilidades reais para uma reorientação da política agrária, entretanto as ações postas pelo governo não comtemplaram um enfrentamento à questão fundiária, como mostra o Gráfico 03 que no primeiro mandato do presidente Lula não existiu uma política efetiva de reforma agrária, sendo que do total das famílias assentadas 44\% ocorreram sem desapropriação e do total da área destinada para reforma agrária, apenas 19,8\% ocorreu via desapropriação. Por outro lado, criam-se mecanismos para possibilitar a desmobilização dos movimentos sociais, que aos poucos foram cooptados por um discurso de pacificação, fundamentado no paradigma do capitalismo agrário, posteriormente evoluindo para o desenvolvimento rural.

Gráfico 03 - Percentual de assentamentos criados, famílias assentadas e área destinada para reforma agrária no $1^{\circ}$ Mandato de Lula

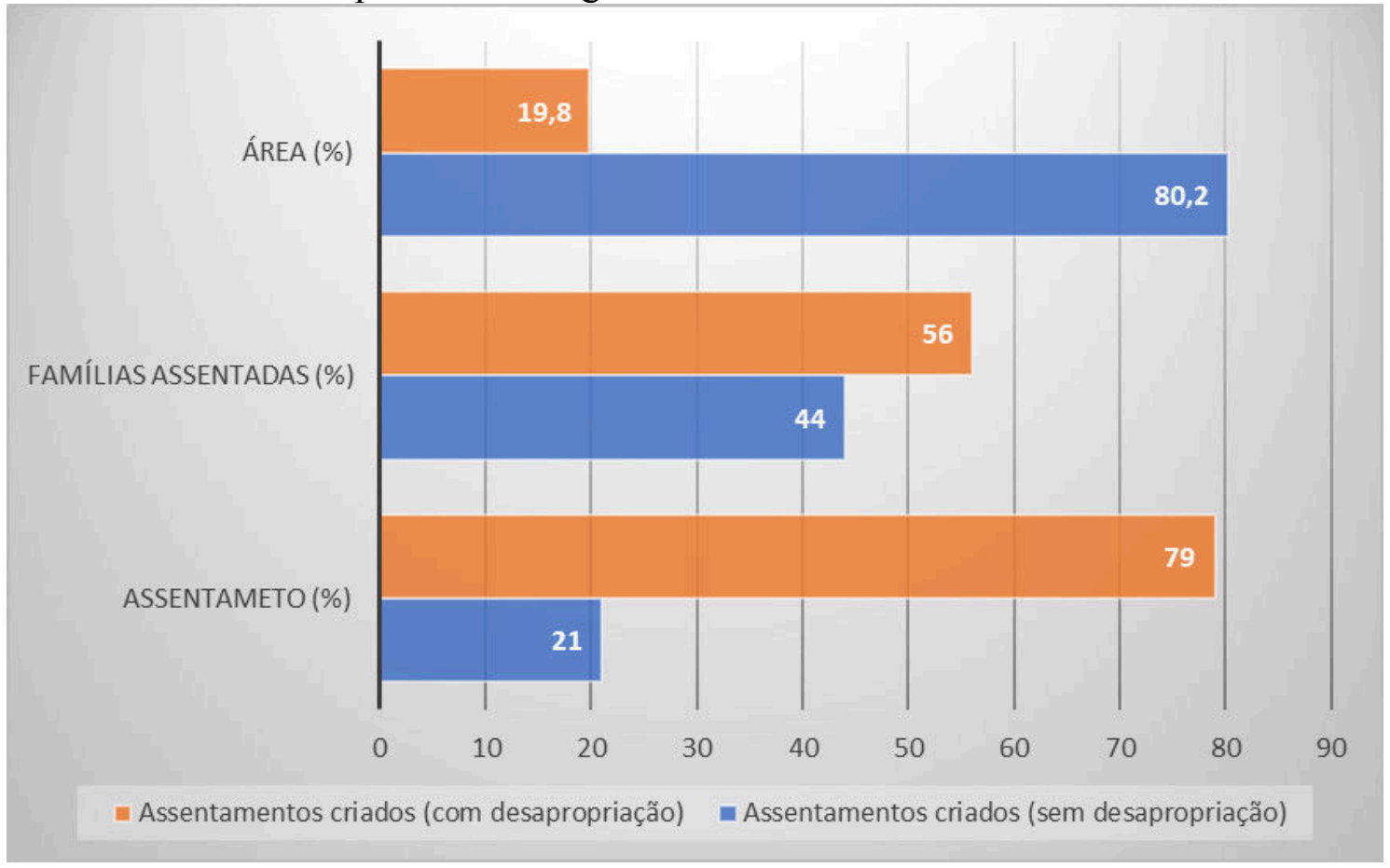

Fonte: Adaptado de Girardi, 2017.

Focado no discurso da redução da pobreza e da ampliação da seguridade social, o governo Lula não foi capaz de enfrentar o grande capital, sendo que em regiões como a Amazônia tornou legal o que era antes crime, isto é, o processo de grilagem passou a ser regularizado e apresentado como reforma agrária. 
A elite dos proprietários mantém seu padrão predatório de sempre. A grilagem de terra, covarde e assassina como sempre, foi e ainda é uma espécie de acumulação primitiva de capital eterna no Brasil. Os grandes latifundiários aumentavam sua terra e riqueza pela ameaça e pelo assassinato de posseiros e vizinhos, como aliás, acontece ainda hoje (SOUZA, 2017, p. 107).

Essas particularidades na política agrária do governo Lula, reafirmaram de forma concreta a continuidade da política de apoio ao agronegócio e de políticas compensatórias para os excluídos do campo. Logo, a desmobilização dos movimentos sociais e a apresentação de um plano com viés economicista para cooptar as demandas populares em benefício da expansão do grande capital no espaço agrário foi articulado.

De acordo com Alentejano e Silva (2007), as famílias assentadas entre 2003 e 2006 foram predominantemente na Amazônia, 70\%. "Ora, se considerarmos que menos de $15 \%$ das famílias que ocuparam terra ou acamparam ao longo deste período, o fizeram na Amazônia, verificamos o total descompasso entre as ações dos movimentos sociais na luta pela terra e a política levada a cabo pelo governo" (ALENTEJANO E SILVA, 2007, p. 80). Dessa forma, Oliveira (2008) analisou a política agrária do governo Lula como uma política de regularização fundiária, se distanciando cada vez mais dos discursos proferidos pelo então presidente ${ }^{5}$, antes de ser eleito. Ou seja, "a política de reforma agrária do governo do PT está marcada por dois princípios: não fazê-las nas áreas de domínio do agribusiness e, fazê-la apenas nas áreas onde ela possa 'ajudar' o agribusiness" (p. 01).

Nesse contexto, apressou-se o planejamento de ações com o objetivo de restringir o conflito de classes e eliminar as barreiras para a expansão e valorização do capital globalizado. Pautado na dinâmica do neoliberalismo, com apoio do Banco Mundial, Instituto Interamericano de Cooperação para a Agricultura (IICA) e a Organização para a Cooperação e Desenvolvimento Econômico (OCDE) o caráter hegemônico do padrão produtivo que envolve o "novo rural" é inserido no planejamento das políticas de desenvolvimento para os países periféricos, em especial na América Latina, definindo as ações prioritárias para o desenvolvimento rural.

O Banco Mundial se apresenta como 'a maior agência multilateral de desenvolvimento'. Há mais de meio século, promove com ideias e financiamentos a ideologia da 'modernização'. Em cada país, o Banco determina a agenda de prioridades, as dificuldades a enfrentar, as possíveis soluções, os parâmetros de avaliação da economia. Alegando não ter melhor alternativa de acesso aos créditos internacionais, os governos acatam as 
orientações do Banco Mundial, deixam de atender problemas vitais de seus povos e abdicam de seus compromissos com a soberania nacional (RESENDE \& MENDONÇA, 2004, p.52).

Nessa mesma perspectiva, Montenegro Gomes (2006) aponta que as propostas contidas nos projetos de desenvolvimento implantadas a partir da década de 1990, tanto pelo governo do presidente FHC, como pelo presidente Lula mantiveram em essência o núcleo de interesse na busca de eficiência produtiva, combater ${ }^{6}$ a pobreza rural e predomínio do mercado como regulador das atividades econômicas. Isso porque elas foram estruturadas tendo como base as exigências do atual padrão produtivo em curso.

Com o início do governo Lula, o conjunto dos atores sociais do campo depositou suas esperanças na reversão desse processo. A expectativa era de que a reforma agrária estaria no centro da agenda política, como uma forma importante de geração de empregos, de garantia da soberania alimentar e como base de um novo modelo de desenvolvimento. [...] O que assistimos é a continuidade das políticas do Banco Mundial para o meio rural (RESENDE \& MENDONÇA, 2004, p. 26).

Nessa conjuntura, a década de 1990 foi referência na desconstrução teórica de padrões produtivos para o campo, aumentando ainda mais o poder do proprietário/capitalista em impedir o acesso à terra e à água aos trabalhadores. Novos conceitos foram sendo incorporados aos debates e à literatura referente ao desenvolvimento rural. A tese em curso baseia-se na negação, negação do conflito entre classes, negação das estruturas de poder que se perpetuam por gerações, absorvendo elementos modernos que encobrem a estrutura arcaica, concentradora e excludente.

Contudo, os intelectuais defensores de um modelo de desenvolvimento sustentável e emancipatório, salientam que a reforma agrária continua sendo uma condição necessária para iniciar esse processo e reverter no longo prazo os efeitos negativos causados pelo modelo produtivista que expande a acumulação capitalista em uma escala cada vez maior. De acordo com Brandão (2012, p. 73) “é preciso muito cuidado no tratamento dessa dimensão 'espacial' do capitalismo, porque ela não tem nada de niveladora de desigualdades. Na verdade, esse processo homogeneizador (de relações mercantis) cria e recria estruturas heterogêneas e desigualdades em seu movimento"

Portanto, houve muito mais continuidade do que ruptura no tratamento dispensado à questão agrária nos governos FHC e Lula, isto é, mantém-se os propósitos com uma abordagem rica em conceitos renomeados e ações que resultaram em dois pontos principais: o apoio ao agronegócio e a desmobilização social. Dessa forma a 
estratégia do desenvolvimento rural, como resposta à crise do capital não contempla os elementos para a solução da crise agrária, atende antes às necessidades do desenvolvimento das forças produtivas, ampliando as relações mercantis necessárias para a reprodução dos valores de troca no mercado globalizado.

\section{O modelo hegemônico de desenvolvimento rural: a unificação do espaço agrário para expansão capitalista}

Para compreender o modelo de desenvolvimento recente adotado no Brasil é necessário buscar sua trajetória no processo histórico de redes interligadas a partir de um mecanismo global de poder, um poder sutil, subjetivo, invisível, mas que comanda a produção do conhecimento, sendo este utilizado para a consolidação dos interesses das classes dominantes na apropriação do espaço. De acordo com Escobar (2007) essa rede de poder controla o conhecimento controla os processos econômicos, políticos, culturais e sociais nos países do terceiro mundo. Por outro lado, não significa negar que as instituições promovem avanços, embora desiguais, para a melhoria de vida nesses países, trata-se, entretanto, de compreender que,

[...] o trabalho das instituições de desenvolvimento não tem sido um esforço inocente feito em favor dos pobres. Isso significa que o desenvolvimento foi bem-sucedido na medida em que foi capaz de integrar, gerenciar e controlar países e populações de maneira cada vez mais detalhada e exaustiva (ESCOBAR, 2007, p. 89) ${ }^{7}$.

As questões que envolvem o papel da agricultura no desenvolvimento capitalista estão sendo fomentadas a partir da elevada taxa de urbanização, queda do emprego agrícola, expansão do agronegócio e expansão das atividades não agrícolas nas áreas rurais. Dessa forma, do ponto de vista das demandas do capital e do atual padrão produtivo, não existe imprescindibilidade da realização de uma reforma agrária para o desenvolvimento rural, ou seja, “[...] do ponto de vista do desenvolvimento capitalista, do ponto de vista do desenvolvimento das forças produtivas no campo, não é mais uma necessidade, seja para a burguesia, seja para as classes produtoras" (GRAZIANO DA SILVA, 2013, p. 169).

Dessa forma, constata-se o ordenamento de um novo modelo de desenvolvimento para o campo brasileiro, pautado em mecanismos e instituições capazes de configurar subjetivamente o espaço agrário, induzindo um processo metodológico de transformação social em que o conflito de classes deixa de existir quando a própria noção 
de classe social desaparece do imaginário, nascendo no meio das contradições da divisão social do trabalho os agentes e atores sociais promotores do desenvolvimento preconizado pela nova ordem mundial.

As abordagens da moda têm abandonado a perspectiva crítica da sociedade, retornando ao conceito de comunidade, constituída por atores e agentes e não classes sociais, que orientariam suas ações pelo compartilhamento dos valores da auto-identidade e do pertencimento a comunas, mas do que por interesses de classe (BRANDÃO, 2012, p. 45).

Essa dinâmica propõe uma (re)configuração do espaço e das atividades rurais. Veiga (2003) chama a atenção para a necessidade de uma nova definição de rural, bem como a emergência de políticas de desenvolvimento rural que promovam a atividade produtiva pelo fortalecimento da pequena produção, ou produção familiar. Para Kageyama (2008, p. 24) "a evolução do conceito de rural reflete a própria evolução do rural, de espaço quase exclusivamente agrícola para um tecido econômico e social diversificado". Nesse contexto, a polarização do debate e das políticas públicas para a abordagem territorial do desenvolvimento tenta alinhar a população rural às novas necessidades do capital, decorrentes do esgotamento do modelo que colocava em lados opostos a dinâmica do agronegócio e o atraso da produção de base familiar.

O modelo de desenvolvimento rural em andamento, tem como locus de atuação os espaços municipais que mantém identidades entre si nas dimensões econômicas, sociais, culturais e ambientais, formando os territórios de identidades. A formação dos territórios segue uma lógica estrutural de planejamento que descentraliza as decisões de planejamento visando o desenvolvimento das potencialidades produtivas dos territórios e de suas populações, homogeneizando os espaços rurais na formatação do processo produtivo de mercadorias e serviços.

Segundo Beduschi Filho e Abramovay (2004, p. 44) "o destino dos territórios deixa de se concentrar numa autoridade ou numa agência central encarregada de distribuir recursos e passa a depender da capacidade de criação de riquezas que a própria interação entre atores locais é capaz de criar”. Por outro lado, Buainain et. al. (2003) chama a atenção para o risco de que a opção pelo desenvolvimento territorial rural, em detrimento do desenvolvimento agrário, possa minar as políticas voltadas para o segmento da produção familiar, transferindo recursos para os produtores e produtos que estão inseridos no mercado globalizado. 
Nesse sentido, tal como ocorreu nos anos 70 e 80, esta visão do novo rural, tal como vem sendo veiculada, presta-se como justificativa intelectual para políticas que em última instância, mantêm o status quo agropecuário do país, caracterizado por forte desigualdade econômica e social, e elevados níveis de pobreza. Com efeito, nos últimos anos, o argumento do novo rural vem sendo utilizado para justificar a necessidade de abandonar políticas agrárias e agrícolas voltadas para os setores mais fragilizados da produção familiar, em benefício de políticas de geração de empregos rurais não agrícolas, limitandose o apoio às atividades propriamente agrícolas das famílias rurais, aquelas consideradas competitivas por ocuparem nichos de mercado, de produtos especiais de alto valor agregado, cuja produção requer o uso intenso de mãode-obra (BUAINAIN, et. al, 2003, p. 03).

A mudança paradigmática tenta colocar uma névoa na questão agrária, ao mesmo tempo dá um colorido especial para as possibilidades que o novo rural cria para o capital.

$\mathrm{O}$ conceito de rural ou de ruralidade não está associado exclusivamente à dimensão agrícola, nem é concebido como um resíduo atrasado do urbano. Pelo contrário, [...] o rural é entendido como um espaço social complexo, portador de três atributos interligados, complementares e indissociáveis: (1) é espaço de produção e de atividades econômicas diversificadas e intersetoriais; (2) é espaço de vida, de organização social e de produção cultural para as pessoas e (3) é espaço de relação com a natureza, o que , ao mesmo tempo, estrutura as características assumidas pelos dois anteriores e determina as condições e as possibilidades de sustentabilidade ambiental e de preservação dos recursos naturais existentes (BRASIL/MDA/CONDRAF, 2013, p, 13-14).

Essa concepção foi essencial para as discussões e estratégias promovedoras de políticas públicas, produção acadêmica e descentralização do Estado na gestão do desenvolvimento rural. Considerando as novas funções do rural para o desenvolvimento econômico do país, as atividades não agrícolas passam a ser estimuladas e regulamentadas para a exploração capitalista. Dessa forma, os agricultores familiares também absorvem a função de se tornarem pluriativos, ou seja, o desenvolvimento de atividades nãoagrícolas, garantindo a (re)produção de um tipo de agricultura familiar que atenda aos interesses mercadológicos da exploração do espaço e dos recursos naturais. De acordo com Schneider (2009, p. 97-98),

Enquanto fenômeno social e econômico presente na estrutura agrária dos países desenvolvidos e em alguns países emergentes, como no caso do Brasil, podemos definir a pluriatividade como um fenômeno através do qual membros das famílias de agricultores que habitam no meio rural optam pelo exercício de atividades não-agrícolas, mantendo a moradia no campo e uma ligação, inclusive produtiva, com a agricultura e a vida no espaço rural. Nesse sentido, ainda que se possa afirmar que a pluriatividade é decorrente de fatores que lhe são exógenos, como o mercado de trabalho não-agrícola ela é uma prática que depende das decisões dos indivíduos ou das famílias. 
Esse novo padrão estabelecido para o campo provoca um reordenamento no mercado de trabalho agrícola, no processo produtivo, e principalmente na forma de acesso à terra, impactando diretamente na descontinuidade social da agricultura familiar camponesa e na luta permanente contra a soberania do capital. Os elementos presentes apontam para medidas que, de um lado aborte o conflito e o fortalecimento dos movimentos sociais na luta pela reforma agrária e pelos direitos dos trabalhadores assalariados e, por outro, que o capital passe a comandar os territórios em escala mundial, regional, nacional, estadual e municipal, através de uma política pública de subordinação.

Dessa forma, existem três aspectos, que são essenciais para a compreensão dessa estratégia. O primeiro, é que essa estratégia é pensada no âmbito das movimentações do capital globalizado, como um movimento que se expande entre as nações. O segundo aspecto, embora contraditório, é que as políticas públicas, concretizadas nas ações do Estado seriam derivadas das deliberações coletivas pertencentes aos territórios, configurando-se em políticas de demanda e não de oferta. E, por último, a redução das funções do Estado, direcionando as suas ações para a regulamentação e/ou desregulamentação de entraves impeditivos do livre movimento do capital, mantendo as condições jurídicas e normativas para o livre funcionamento do mercado.

Com as novas possibilidades para o campo, expande-se o nível de subordinação da agricultura ao capital, sendo que essa expansão ocorre de forma quantitativa com uma maior abrangência do espaço, atividades e de produtores, e qualitativa, pela forma com que o capital altera estruturas econômicas, sociais, culturais e políticas de uma sociedade, redesenhando e unificando espaços para a espoliação mundial.

As ações concretas para o planejamento de políticas para o campo, iniciadas na década de 1990, tiveram continuidade nos anos 2000, basearam-se no paradigma do capitalismo agrário e na tese de que, com o novo rural a reforma agrária não é mais necessária. Primeiramente pelo dinamismo da agricultura patronal e, em segundo, pelo baixo desempenho econômico e elevado índice de abandono nas áreas de assentamentos rurais, impactando negativamente na viabilidade da reforma agrária como medida para reduzir as desigualdades sociais e a pobreza no campo. Contudo, deve se destacar que a defesa pela realização da reforma agrária, preconizada em meados do século $\mathrm{XX}$, decorrentes do pacto entre trabalhadores e burguesia, estava ligada ao desenvolvimento 
das forças produtivas no campo uma vez que a concentração fundiária seria um empecilho para a expansão das relações de produção capitalista no espaço agrário.

\begin{abstract}
Os objetivos gerais das proposições estratégicas hegemônicas no Brasil sobre a reforma agrária desde a década de 1940, a partir de proposições políticas de centro-esquerda, defendiam a necessidade de uma revolução burguesa no campo para eliminar ora os restos feudais, ora o latifúndio improdutivo de maneira a permitir o desenvolvimento das forças produtivas sob o padrão de produção capitalista, a valorização do trabalho pelo assalariamento e a criação de um mercado interno. [...] No âmbito dessa perspectiva, a reforma agrária, a partir dos pressupostos de uma revolução burguesa, constituiria, por um lado, pequenos e médios produtores rurais em condições de incorporarem as tecnologias capitalistas modernas para o campo (CARVALHO, 2013, p. 129).
\end{abstract}

Nesse caso, a tese construída de que a reforma agrária é algo ultrapassado, desnecessária frente aos atuais padrões produtivos que o rural oferece, alicerça uma ideologia dominante sobre a temática, afirmando que esta política não atende à demanda distributiva, mas à produtivista. Para um resultado mais rápido e eficiente na disputa pelo modelo a ser viabilizado essa tese fundamentou-se em alguns pressupostos, examinados por Leite (2013).

1) $\mathrm{O}$ aumento da produção e do emprego no campo, e portanto do combate à pobreza no meio rural, será resolvido pelo modelo produtivista do chamado agronegócio; 2) A reforma agrária é uma tese ultrapassada e obsoleta, incompatível com o atual estágio do capitalismo brasileiro e não apresenta nenhum impacto econômico na sociedade; 3 ) Com a modernização da agricultura, esgotou-se a disponibilidade de terras não aproveitadas, salvo aquelas situadas na Amazônia e no cerrado, não recomendadas para a reforma agrária; 4) A reforma agrária é um programa com elevado custo financeiro para sua realização e pouca capacidade de geração de novos postos de trabalho; 5) Os projetos de assentamentos já implantados possuem baixa qualidade, gerando um processo de favelização na área rural; 6) A maioria das famílias instaladas nos assentamentos não está vocacionada para a agricultura, comprometendo o sucesso do programa de reforma agrária.

Esses pressupostos foram defendidos e difundidos pelas pesquisas e reproduzidas em boa parte da produção acadêmica para que pudessem se articular com as atuais forças de mercado que comandam o movimento do capital para a implementação de um modelo hegemônico no espaço agrário, favorecendo o planejamento de políticas públicas que atendessem às exigências do padrão produtivo que demanda novos espaços 
para sua valoração. Por outro lado, esse viés apontou uma ressignificação para a reforma agrária, tornando-a indispensável para o desenvolvimento sustentável, ou seja,

[...] houve um deslocamento do foco: contestando o modelo produtivista, apontando os riscos dos insumos químicos e das biotecnologias para a saúde e defendendo a soberania alimentar, passaram a progressivamente valorizar a agroecologia, resgatando experiências tradicionais e camponesas, defendendo um novo modelo de produzir, independente das grandes empresas produtoras de insumos e sementes, e buscando valorizar as articulações mercantis locais e regionais (MEDEIROS, 2015, p. 353-354).

O modelo de desenvolvimento adotado para o campo no final do século XX foi estruturado a partir da incorporação de novos conceitos e destruição de outros, buscado o reordenamento das funções do Estado e do espaço agrário, que deve ser territorializado pelo capital para exploração capitalista, viabilizando o desenvolvimento de novas forças produtivas que elevam o sistema a outro patamar de acumulação. Outra ação significativa para a operacionalização desse modelo está no alinhamento das políticas com a escala de abrangência de acumulação de capital.

É inconteste que o movimento da acumulação de capital se processa em sua expressão espacial, de forma mutável, parcial, diversa, irregular e com alta seletividade. As manifestações no espaço da valorização e da riqueza são altamente discriminatórias. Existe, assim, um processo de busca e seleção por pontos de espaço que oferecem maior capacidade de apropriação privada de rendimentos e onde 'valorizar o valor' seja mais fácil (BRANDÃO, 2012, p. 52-53).

Ainda de acordo com Brandão (2012, p. 67) "é preciso mergulhar no concreto e no histórico para captar e apreender as manifestações concretas dos fenômenos inerentes à dimensão espacial do processo de desenvolvimento capitalista em cada situação específica". Ou seja, a espacialidade é determinada pelo próprio movimento desigual e combinado do capital que determina a escala do desenvolvimento e, na mesma medida que destrói escalas constrói outras. Dessa forma, a escala determinada como mais eficiente para a valorização do capital não poderia ser restrita ao local, nem tão abrangente como a regional. Tendo o espaço rural como estratégia de expansão capitalista o território passa a ser o locus dos processos econômicos e sociais em que se articula o novo padrão de desenvolvimento hegemônico gestado em escala mundial e institucionalizado no espaço brasileiro pelo governo Lula nos anos 2000.

Portanto, na primeira década do século XXI emerge uma nova formatação dos debates, conceitos, instituições e políticas voltadas para o desenvolvimento rural. A política de base para a implementação desse modelo iniciou-se com a proposta do 
desenvolvimento de uma agricultura familiar capitalista, tendo no governo FHC sua gênese com a criação do Programa Nacional de Fortalecimento da Agricultura Familiar (PRONAF), “com a finalidade de promover o desenvolvimento sustentável do segmento rural constituído pelos agricultores familiares, de modo a propiciar-lhes o aumento da capacidade produtiva, a geração de emprego e a melhoria de renda" (BRASIL/MDA/CONDRAF, 2013, p. 11). Esse padrão, encontra sua efetiva sustentação na política de desenvolvimento territorial rural (DTR), tornando-se um dos principais eixos de atuação do governo Lula no planejamento do desenvolvimento rural brasileiro.

O conceito de desenvolvimento rural não é entendido como modernização agrícola, nem como industrialização ou urbanização do campo. O desenvolvimento está associado à ideia de criação de capacidades - humanas, políticas, culturais, técnicas etc. - que permitem às populações rurais agir para transformar e melhorar suas condições de vida, por meio de mudanças em suas relações com as esferas do Estado, do mercado e da sociedade civil (BRASIL/MDA/CONDRAF, 2013, p. 13).

Nesse período foram consolidados o conceito de agricultura familiar e uma estrutura de crédito para o desenvolvimento e fortalecimento desse segmento, partindo de uma tipologia em relação aos agricultores, definiram-se os beneficiários. O governo Lula avança, tanto nos debates ideológicos sobre a temática quanto no planejamento das políticas para o campo, tendo como princípio fundamental o território como escala de planejamento.

\footnotetext{
A política de desenvolvimento rural e de apoio à agricultura familiar do Brasil apresentou uma mudança significativa a partir do ano de 2003, devido ao seu caráter explicitamente territorial, com a adoção de uma estratégia que implicou na criação de uma estrutura institucional e de um conjunto de processos de gestão da política pública que marcou um novo rumo às políticas de desenvolvimento agrário (ECHEVERRI, 2010, p. 82).
}

De acordo com Cazella et all (2016) é possível estabelecer três fases para o modelo de desenvolvimento rural no Brasil, excluindo a fase de sua extinção. A primeira fase inicia-se com as pressões e demandas dos movimentos sociais pela reforma agrária e a degradação das relações de trabalho no campo, consequências do modelo de desenvolvimento agrícola implementado. A segunda teve como característica a ampliação das políticas e programas sociais como a universalização da seguridade social para os trabalhadores do campo e o Programa Bolsa Família ${ }^{8}$. A terceira fase teve como foco o estímulo à inserção ao mercado, incluindo a valorização de produtos oriundos da 
agricultura familiar e o acesso da população rural ao mercado consumidor de bens industrializados.

Para Montenegro Gomez (2006) de fato o que envolve a temática do DTR é o caráter político administrativo para a implementação das políticas públicas de desenvolvimento capitalista, "cujo alvo é o meio rural e que prioritariamente se referem a projetos de infraestrutura, capacitação, apoio ao associativismo e cooperativismo e apoio ao comércio e ao desenvolvimento de negócios” (p. 270). Dessa forma, o capital se apropriou de uma concepção de desenvolvimento que emergiu no âmbito dos movimentos sociais e Ong's, a sustentabilidade ambiental. Para Guzmán e Molina (2013), as estratégias que envolvem o ecodesenvolvimento têm sido desarticuladas pelo capital, pois sua estratégia é "a apropriação capitalista da natureza, sua introdução no processo produtivo de mais-valia e sua circulação como mercadorias" (p. 60). Portanto os problemas decorrentes da penetração do capitalismo no campo não poderão ser superados pelo próprio sistema, mas pela superação do próprio capitalismo.

Aqui é possível perceber o ponto de inflexão envolvendo o Governo os organismos internacionais e intelectuais unidos para a construção e fortalecimento de um modelo hegemônico de desenvolvimento para o campo que possibilite a expansão do capital em todas as escalas, unificando os espaços para a reprodução ampliada do capital. Dessa forma, concretiza-se a proposta defendida pelos pró-desenvolvimento das relações capitalistas de produção como alternativa aos problemas agrários, nessa lógica consolidase o DTR como o instrumento de ampliação das relações de produção capitalistas no campo, intensificando a subordinação do campesinato ao avanço do agronegócio e a espoliação do espaço rural pelo capital.

Assim, o poder hegemônico deverá ter poder de enquadramento e hierarquização de relações, processos e estruturas, e ser o portador do novo (por exemplo, o domínio tecnológico). Deverá ter capacidade de iniciativa, de 'endogenia de desenvolvimento', de regulação e de administração dos limites e possibilidades de si e dos outros. [...] Dada uma certa correlação de forças, consideradas em determinado tempo-espaço, é preciso perscrutar a força coercitiva, os níveis e graus de 'consentimento' para o domínio e exercício de direção que consolide um determinado 'projeto de incorporação de todos' em sua órbita. [...] O ser hegemônico necessita ser minimamente 'dono do seu próprio destino', ter preeminência, supremacia e capacidade de ser o condutor do processo para ter força suficiente para propor, articular e sustentar uma determinada unidade e aliança e administrar e centralizar uma 'coesão nacional imaginária', que se exerce sobre determinados grupos subordinados (BRANDÃO, 2012, p. 84). 
O discurso da amabilidade entre opressor e oprimido representa uma das mais perversas facetas do capital que, cada vez mais necessita expropriar o camponês, inicialmente tira-lhes os meios de produção e agora a sua identidade, passando de camponês para agricultor familiar, este agora parceiro e não antagônico ao capital. Um ponto a destacar é que o arcabouço teórico produzido para a sustentabilidade ideológica do modelo de desenvolvimento rural busca promover uma mudança social e cultural na relação do camponês com a natureza, despindo-o da sua formação social enquanto classe, transformando-o em agricultor familiar.

Portanto, evidencia-se uma forte ameaça às identidades culturais e sociais das comunidades rurais agora comandadas pelas forças do mercado e transformadas em relações mercantis. Para Fernandes (2001, p. 31) "A questão é se o camponês luta contra o capital ou aceita esse destino". Surge, dessa forma um processo de diferenciação entre campesinato e agricultura familiar e nesse processo, este sujeito social, o camponês, seria incompatível com o modo de produção capitalista. Assim sendo, as bases desse modelo de desenvolvimento rural incluem uma mudança paradigmática do agrário para o rural e a metamorfose do camponês em agricultor familiar. Para Abramovay (1998) a mudança de concepção teórica em relação ao destino dos camponeses, encontra um forte argumento para o fortalecimento da agricultura familiar em questão.

As políticas públicas, de fortalecimento da agricultura familiar, promoveram a legítima continuidade do modelo neoliberal durante o governo Lula, através do aparato institucional as proposições levantadas sobre o DTR sugerem que essa lógica produtivista favorece cada vez mais a acumulação de capital através da expropriação dos recursos tangíveis e intangíveis, ao mesmo tempo em que desfaz os verdadeiros laços de cooperação e confiança, corroendo as bases necessárias para desvendar as mediações que alicerçam esse processo. Para Fernandes et. al. (2009, p. 23)

\begin{abstract}
As lutas camponesas são sinais da resistência do campesinato contra a desterritorialização. Compreendendo o território como espaço de realização da vida em suas diferentes dimensões (econômicas, sociais, culturais, políticas etc.), entende-se melhor não só a existência de diferentes formas que o campesinato assume, como também a diversidade de lutas verificadas no campo, com o sentido de garantir a existência dessa categoria social num contexto em que ocorre intenso processo de expropriação.
\end{abstract}

Nesse sentido, a ideologia dominante mina as forças de resistência à lógica de acumulação capitalista no espaço rural, incorporando novos conceitos, tais como capital 
humano, capital social, atores sociais e participação política. Esses conceitos tornam-se essenciais para a compreensão da engrenagem que coloca em movimento as articulações do capital em direção aos pobres excluídos de fases anteriores do desenvolvimento do capitalismo no campo. As mudanças são operadas inicialmente com a produção teórica e a popularização de conceitos e categorias, operacionalizados como uma ponte para a expansão das relações capitalistas de produção no campo.

Para Abramovay (2000, p. 04) "as estruturas sociais devem ser vistas como recursos, como ativo de capital de que os indivíduos podem dispor”. Essa tendência foi evidenciada em Marx e abordada por Quaini (2002) que discute a progressiva ação do capitalismo nos territórios, em que este transforma os meios de produção e as forças produtivas em mercadorias, "onde o trabalho não se apresenta como produtor de valores de uso, mas como medida geral das coisas, dos produtos, onde as relações sociais não se apresentam como relações pessoais, mas como relações entre coisas" (p. 66).

Para Fernandes $(2015$, p. 397) "a elaboração de políticas para promover o desenvolvimento são possibilidades de construção de alternativas, pois uma política pode fortalecer ou enfrentar o sistema hegemônico". Entretanto a construção de um modelo participativo e descentralizado, inclui várias instâncias governamentais e da sociedade civil organizada promovendo fóruns e conferências para as discussões e produção de projetos para viabilizar a permanência da população no campo, abrindo espaço para que suas demandas sejam ouvidas, e que a luta pela sua existência enquanto classe seja permanente. Esse momento de participação política das comunidades pode ser muito importante para a inserção de muitos povos, antes excluídos das políticas públicas, alterando o rito das ações governamentais, que teoricamente ocorre no âmbito dos colegiados com efetiva participação dos atores sociais e, onde antes tinham-se políticas de oferta agora propõe-se políticas de demanda, permitindo uma mediação social, política e econômica entre Estado e sociedade.

Nesse contexto, a institucionalização da política de desenvolvimento territorial rural (DTR) foi estabelecida, considerando o 'novo rural' como o espaço de planejamento para as políticas públicas para o campo. Dessa forma, temas como sustentabilidade e segurança alimentar tiveram uma forte influência para o planejamento das ações nos territórios para o fortalecimento do segmento da agricultura familiar, garantindo a sua subordinação a dinâmica do desenvolvimento rural que integra os capitais agrários, 
industriais e financeiros no mesmo espaço, onde todos os elementos humanos e naturais estão condicionados ao mercado globalizado.

\section{Considerações Finais}

Considerando o que foi discutido até aqui, buscou-se uma reflexão crítica sobre o modelo de desenvolvimento rural, considerado como uma continuidade das políticas implementadas no final dos anos de 1990. Dessa forma algumas ações basilaram esse modelo na década nesse período: a criação do Pronaf em 1996, O Programa Bolsa Escola e, principalmente a criação do MDA em 1999. Analisando as ações empreendidas e o discurso político na construção de um novo modelo de desenvolvimento para o campo brasileiro, evidencia-se que, de mãos dadas com o grande capital e as velhas oligarquias, o gov. Lula seguiu na promoção do desenvolvimento rural. Ou seja, mais uma vez o velho se reveste do novo e, promove as mudanças necessárias para que tudo permaneça como está.

Contudo, a medida que a sociedade se move, seja através de estímulos externos ou pelas ações coletivas desenvolvidas a partir do contexto das suas demandas, criam-se condições para uma maior participação nas esferas políticas, econômicas e sociais, tornando-se determinantes para a organização de novos saberes e processos produtivos nos espaços (re)criados, principalmente pela reforma agrária. Portanto, houve nos anos 2000 uma efetiva integração entre o capital industrial, o capital financeiro e o latifúndio. Nesse contexto a abordagem do DTR é concretizada a partir da cooperação e integração entre várias instituições internacionais, como Banco Mundial, IICA e OCDE e com o Estado que através do Ministério do Desenvolvimento Agrário e Secretaria do Desenvolvimento Territorial atuaram no processo de planejamento e execução das políticas públicas direcionadas à expansão do capital nos territórios.

Dessa forma, as ações refletem um percurso de caráter conservador, objetivando em essência barrar uma possível mudança social no campo. Nesse sentido, a mudança paradigmática do agrário para o rural atende a dois objetivos: criar um espaço para a expansão capitalista e, promover a desmobilização social diante da ofensiva do capital no espaço agrário. Evidencia-se portando que o DTR apresenta um caráter de integração entre capitais a montante e a jusante em busca de uma hegemonia espacial no processo de acumulação, em que as grandes corporações comandam as decisões políticas e 
econômicas no mundo globalizado unificando os espaços para o movimento crescente de acumulação de capital.

\section{Notas}

1. Texto extraído da Tese de doutorado, ainda em desenvolvimento no Programa de Pós-Graduação em Geografia da Universidade Federal da Paraíba (PPGG/UFPB).

2. Para uma compreensão detalhada do conceito de movimentos socioterritoriais ver FERNANDES (2005).

3. coordenado por Graziano da Silva na década de 1990,

4. É importante frisar que a criação de novos assentamentos nem sempre significa a desterritorialização do latifúndio em favor da reforma agrária. Quando ocorre a criação de assentamentos em áreas públicas ou em áreas de preservação ambiental estes não contribuem para a alteração da estrutura fundiária do País. Dessa forma a criação de novos assentamentos deve ser analisada considerando a sua efetividade quanto a uma reforma agrária orgânica.

5. "Se um dia for presidente da República do Brasil e puder fazer apenas uma única coisa, podem ter certeza que essa coisa será a reforma agrária". (Luíz Inácio Lula da Silva, IV Congresso Nacional do MST, 2000. In: Alentejano \& Silva, 2007, p. 85).

6. De acordo com Montenegro Gomes (2006), a tradução literal do texto contido nos documentos oficiais do Banco Mundial seria "alívio", tendo sido traduzido como "combate", indicando que em essência, o modelo de desenvolvimento tem como objetivo o controle social, uma vez que não propõe combater as questões estruturais que geram a pobreza.

7. [...] "el trabajo de las instituciones de desarrollo no ha sido un esfuerzo inocente hecho en nombre de los pobres. Significa que el desarrollo ha tenido éxito en la medida en que ha sido capaz de integrar, administrar y controlar países y poblaciones en formas cada vez más detalladas y exaustivas" (ESCOBAR, 2007, p. 89).

8. O programa original foi criado em 2001 como Bolsa Escola, tendo um grande efeito na redução do trabalho infantil.

\section{REFERÊNCIAS}

ABRAMOVAY, Ricardo. O capital social dos territórios: repensando o desenvolvimento rural. Economia Aplicada, v. 4, n. 2, p. 379 - 397, abr./jun. 2000. 1998. $275 \mathrm{p}$.

Paradigmas do capitalismo agrário em questão. 2. ed. Campinas: Hucitec,

ALENTEJANO, Paulo.; SILVA, Thiago Lucas da. Ocupações, acampamentos e assentamentos: o descompasso entre a luta pela terra e a política agrária do governo Lula. In: CANUTO, Antonio. et. al. (Coord.) Conflitos no campo / CPT Nacional. Goiânia, 2007. 240 p. p. $79-85$.

BEDUSCHI FILHO, Luiz Carlos; ABRAMOVAY, Ricardo; Desafios para o desenvolvimento das regiões rurais. Nova Economia. Belo Horizonte, v, 14, n. 3, p.35 -70 , set./dez. 2004.

BRANDÃO, Carlos. Território e desenvolvimento: as múltiplas escalas entre o local e o global. Campinas, SP: Editora da Unicamp, 2012. 238 p. 
BRASIL/MDA/CONDRAF. Documento de Referência: $2^{\text {a }}$ Conferência Nacional de Desenvolvimento Rural Sustentável e Solidário. Brasília, 2013. 72 p. Disponível em: http://www.mda.gov.br/sitemda/sites/sitemda/files/user_arquivos_64/Documento_de_R eferencia_2CNDRSS.pdf. Acesso em 23 de julho de 2017.

BUAINAIN, Antônio M.; ROMERO, Aldemar R.; GUANZIROLI, Carlos E. Agricultura familiar e o novo mundo rural. Sociologias, Porto Alegre, ano 5, n. 10, p. 312-347. Jul/dez. 2003.

CARVALHO, Horácio Martins. Uma ressignificação para a reforma agrária no Brasil: texto I - teses. In: STÉDLE, João Pedro (org.). A Questão agrária no Brasil: debates sobre a situação e perspectivas da reforma agrária na década de 2000. São Paulo: Expressão Popular, 2013. 242 p. p. 127 - 140.

CAZELLA, Ademir A. et. all. Políticas públicas de desenvolvimento rural no Brasil: o dilema entre inclusão produtiva e assistência social. Política \& Sociedade - vol. 15, edição Especial, 2016, p. 49 - 79.

COMISSÃO PASTORAL DA TERRA. Conflitos no campo. Disponível em: https://www.cptnacional.org.br/biblioteca-virtual. Acesso em 22 de junho de 2018.

ECHEVERRI, Rafael. Emergência e evolução do programa de desenvolvimento sustentável dos territórios rurais e nos territórios da cidadania. In: FAVARETO, Arilson. et. al. (Org.) Políticas de desenvolvimento territorial rural no Brasil: avanços e desafios. Brasília: IICA, 2010 (Série Desenvolvimento Rural Sustentável; v. 12). 220 p. p. $81-114$.

ESCOBAR, Arturo. La Invención del tercer mundo. Construcción y deconstrucción del desarrollo. $1^{\text {a }}$. ed. Caracas, Venezuela: Fundación Editorial el perro y la rana. Traducción de Diana Ochoa, 2007. 424 p.

FERNANDES, Bernardo M.; MEDEIROS, LEONILDE S. de.; PAULILO, Maria I. (Orgs.) Lutas camponesas contemporâneas: condições, dilemas e conquistas: a diversidade das formas das lutas no campo. São Paulo: Editora da UNESP; DF: NEAD, 2009. (Vol.II). 369 p.

FERNANDES, Bernardo M. Reforma agrária no governo Lula: a esperança. Presidente Prudente: UNESP/NERA, 2003. Disponível em: http://www2.fct.unesp.br/nera/publicacoes/LULA_RA.pdf. Acesso em 19 de abril de 2018. $07 \mathrm{p}$.

Políticas públicas, questão agrária e desenvolvimento territorial rural no Brasil. In: In: GRISA, Cátia e SHNEIDER, Sergio (Ogs.). Políticas Públicas de desenvolvimento rural no Brasil. Porto Alegre: Editora da UFRGS, 2015. 625 p. p. $381-400$. 
. Questão agrária, pesquisa e MST. Coleção Questões da nossa época, v. 92. São Paulo: Editora Cortez, 2001. 120 p.

GIRARDI, Eduardo Paulon. Atlas da Questão Agrária Brasileira. Presidente Prudente: UNESP/NERA, 2017. Disponível em: www.atlasbrasilagrario.com.br. Acesso em: 15 de junho de 2018.

GRAZIANO DA SILVA, José. O Desenvolvimento do capitalismo no campo brasileiro e a reforma agrária. In: STEDILE, João Pedro (Org.). A Questão agrária no Brasil: o debate na década de 1990. São Paulo: Expressão Popular, 2013. 388 p. p. 163 - 170.

GRAZIANO DA SILVA, José; GROSSI, Mauro Del; CAMPANHOLA, Clayton. O que há de realmente novo no rural brasileiro. Cadernos de Ciência \& Tecnologia, Brasília, v. 19, n. 1, p. 37-67, jan./abr. 2002.

GUZMÁN, Eduardo S.; MOLINA, Manuel G. de. Sobre a evolução do conceito de campesinato. 2ed. São Paulo: Expressão Popular, 2013. 96 p.

KAGEYAMA, Angela. Desenvolvimento rural: conceito e aplicação ao caso brasileiro. Porto Alegre: Editora da UFRGS: Programa de Pós-Graduação em Desenvolvimento Rural, 2008.

LEITE, Sergio. Seis comentários sobre seis equívocos a respeito da reforma agrária no Brasil. In: STÉDLE, João Pedro (org.). A Questão agrária no Brasil: debates sobre a situação e perspectivas da reforma agrária na década de 2000. São Paulo: Expressão Popular, 2013. 242 p. p. $103-126$.

MEDEIROS, Leonilde Servolo de. Luta por reforma agrária no Brasil contemporâneo: entre continuidades e novas questões. In: GRISA, Cátia e SHNEIDER, Sergio (Ogs.).

Políticas Públicas de desenvolvimento rural no Brasil. Porto Alegre: Editora da UFRGS, 2015.625 p. p. $339-359$.

MONTENEGRO GÓMEZ, Jorge R. Desenvolvimento em (des)construção: narrativas escalares sobre desenvolvimento territorial rural. Presidente Prudente. 2006. 438 f. Tese (Doutorado em Geografia) apresentada na Universidade Estadual Paulista - UNESP.

NERA/DATALUTA. Relatórios DATALUTA. Presidente Prudente, UNESP, 2014. Disponível em: http://www2.fct.unesp.br/nera/. Acesso em 23 de junho de 2018.

OLIVEIRA, Ariovaldo Umbelino de. Não Reforma agrária e contra reforma agrária no Brasil do governo Lula. 2008. Disponível em:

http://observatoriogeograficoamericalatina.org.mx/egal13/Geografiasocioeconomica/Ge ografiaagraria/04.pdf. Acesso em: 19 de abril de 2018. 19 p.

PEREIRA, João Márcio M. A Luta política em torno da implementação do modelo de reforma agrária de mercado durante o governo Cardoso. In: STÉDLE, João Pedro (org.). 
A Questão agrária no Brasil: debates sobre a situação e perspectivas da reforma agrária na década de 2000. São Paulo: Expressão Popular, 2013. 242 p. p. 19 - 68.

QUAINI, Massimo. Marxismo e geografia. Tradução de Liliana L. Fernandes. 3.ed. Rio de Janeiro: Paz e Terra, 2002. 155 p.

RESENDE, Marcelo; MENDONÇA, Maria Luisa. As Políticas do Banco Mundial para a estrutura fundiária brasileira: armadilhas do mercado de terras. Brasília: Rede Social de Justiça e Direitos Humanos, 2004. 79 p.

SCHNEIDER, Sergio. A Pluriatividade na agricultura familiar. 2.ed. Porto Alegre: Editora da UFRGS, 2009. 258 p.

SACHS, Ignacy. Brasil rural: da redescoberta à invenção. Estudos Avançados (15) 43, p. $74-82.2001$.

SILVA, Anderson Antonio da.; FERNANDES, Bernardo Mançano. Ocupações de terras - 2000 - 2005: Movimentos socioterritoriais e espacialização da luta pela terra. In: COMISÃO PASTORAL DA TERRA. Conflitos no campo - Brasil 2004 [Coordenação: Antonio Canuto, Cassia Regina da Silva Luz e José Batista G. Afonso] [Goiania]: CPT Nacional Brasil, 2005.

SOUZA, Jessé. A Elite do atraso: da escravidão à lava jato. Rio de Janeiro: Leya, 2017. $239 \mathrm{p}$.

VEIGA, José Eli da. Cidades imaginárias: o Brasil é menos urbano do que se calcula. $2^{\mathrm{a}}$ ed. Campinas/SP: Autores Associados, 2003. 